\title{
Marriage Properties Sharing Based on Islamic Law
}

\author{
Sudirman A. Dg. Mataro ${ }^{*}$, M. Taufan B ${ }^{2}$, Ermawati Ermawati ${ }^{3}$
}

${ }^{1}$ Islamic Family Law Department, Postgraduate, Institut Agama Islam Negeri Palu

2 Islamic Family Law Department, Postgraduate, Institut Agama Islam Negeri Palu

${ }^{3}$ Islamic Family Law Department, Postgraduate, Institut Agama Islam Negeri Palu

ABSTRACT
The aim of this study is to discuss the Sharing of Assets as a
Result of Divorce in the Palu Religious Court. This study used
qualitative research methods with an emphasis on juridical
analysis studies/ The data was gathered through
observation, interviews, and documentation. The data
analysis technique that the researcher uses is data reduction,
data presentation, data verification and conclusion. This study
found that, the distribution of shared assets in the Palu
Religious Court, the Panel of Judges in completing the
distribution of assets referred to Article 35 paragraph (1) of
Law Number 1 of 1974 and KHI in article 97 . In determining
and granting the plaintiff's claim and the plaintiff's
reconstruction which contains the Determination of joint
assets according to the provisions of the marriage law, that the
assets obtained during marriage become joint property. In a
legal juridical sense, the understanding of shared property is
the property of husband and wife obtained during marriage.

ARTICLE

INFORMATION

The aim of this study is to discuss the Sharing of Assets as a

Keywords:

Marriage properties, sharing, Islamic law 


\section{Introduction}

Joint property can only be divided if the marital relationship is terminated due to death. It has definite legal provisions from the time of the death of one of the parties, formally from that moment the joint property may be divided by involving the parties concerned. If the judge's decision that determines the termination of the marriage relationship does not have definite power, then the joint property between husband and wife cannot be divided.

According to the Jurisprudence of the Supreme Court of the Republic of Indonesia dated October 9, 1968 Number 89K/Sip/19689, as long as a widow does not remarry and during her life the joint property is held by her, it cannot be divided to ensure her livelihood. In Article 156 of the Complication of Islamic Law, it is stated that the dissolution of a marriage due to divorce on joint property is that the joint property is divided according to the provisions as referred to in Article 97 which contains the provision that the divorced widow is each entitled to one-half of the joint property as long as it is not specified otherwise in the marriage agreement. ${ }^{1}$

The provisions in Presidential Instruction Number 1 of 1991 concerning the Complication of Islamic Law Article 97 and in line with the provisions of the Civil Code states that the method of

1 Sukaenah, Sukaenah, Rusli, Rusli, \& B, M. Taufan. (2020). The Effectiveness of Indonesia Supreme Court Regulation Number 1 Year 2016 Concerning Mediation of Marriage Disputes International Journal of Contemporary Islamic Law And Society, 2(1), 63-80; distribution is by dividing equally; each (husband and wife) gets half a share of the gono-gini property. This joint property cannot be equated with inheritance, because inheritance is inherited property, not joint property. Therefore, the inheritance cannot be divided in the division of the property as a result of divorce. ${ }^{2}$ This is what the Religious Courts hold in deciding the distribution of these gono-gini assets.

In the Marriage Law Number 1 of 1974, the authority to adjudicate disputes over joint property for Muslim people was initially a matter of dispute. This is because Article 35 and Article 36 of the Law do not explicitly state that disputes over joint property for Muslim people are resolved through Religious Courts.

In fact, it appears that the Religious Courts have the authority to settle them, as seen in Article 37, "If the marriage is dissolved due to divorce, the joint property is regulated according to their respective laws." This article should be interpreted in general terms, so that if the person in dispute is a Christian, then the settlement is according to their law. Likewise, if the disputed is Muslim, then it is settled according to Islamic law. However, because disputes over joint property are still considered to be included in customary law institutions, the authority remains with the District Court, even if the person in dispute is a Muslim.

After the enactment of Law Number 7 of 1989 concerning the

2 See Rusli Rusli, "Hermeneutical Reading of Ṭalāq," HUNAFA: Jurnal Studia Islamika 12, no. 2 (2016): 209-229. 
Religious Courts on December 29, 1989, through Article 49 and the explanation of Paragraph (2) point (10), it was emphasized that "what is meant by the field of marriage as regulated in Law Number 1 of 1974 concerning marriage, among others, is the settlement of joint property." 3

The provisions regarding the distribution and the portion of the acquisition of each husband and wife from the joint property in the case of divorce, are found in the provisions of Article 96 and Article 97 Complications of Islamic Law. Article 96 reads:

1. If divorce occurred because of death, then half of the joint property becomes the right of the spouse for a longer life.

2. The distribution of joint property for a husband or wife whose wife or husband is missing must be postponed until there is certainty of death based on reality or legality according to religious court decision. ${ }^{4}$

Article 97 states that divorced widows or widowers are each entitled to one-half of the joint property as long as there is no other provision in the marriage agreement. ${ }^{5}$ The articles above emphasize that the distribution of joint property between husband and wife who is divorced or widowed, or because one of them is missing, each of them gets half or half of the joint property.

In the distribution of joint property, it is no longer taken into account who

${ }^{3}$ Dedi Susanto, Kupas Tuntas Masalah Harta Gono-Gini (1 ${ }^{\text {st }}$ Edition, Yogyakarta: Pustaka Yustisia, 2011), 144.

${ }^{4}$ Abdurrahman, Kompilasi Hukum Islam, 140

${ }^{5}$ Ibid. works, and in whose name the joint property is registered. As long as the property is acquired during the marriage period, in accordance with Article 35 and Article 36 of the Marriage Law, the acquired property is joint property, and is divided in half between husband and wife. ${ }^{6}$

\section{Literature Review}

\subsection{Definition and Legal Basis of Joint- Property}

The theory used in this paper is the theory of justice. Before entering into the discussion in the theory of justice, the author will explain what the goals and functions of the theory in research. Theory in question is a description of the thoughts or points of opinion set forth in the thesis. ${ }^{7}$ Theory is useful for explaining why specific phenomena or certain processes occur, and a theory occurs must be tested by confronting it with facts that can show the untruth. The continuity of the development of science of law, depending on the methodological research activities, is largely determined by theory. ${ }^{8}$

Theory follows certain rules that can be connected logically with one

6 Yunus, Haerunnisa, Rusli, Rusli, \& Abidin, Abidin. (2020). The Concept of A Marriage Agreement in the Compilation of Islamic Law International Journal Of Contemporary Islamic Law And Society, 2(2), 35-45.

${ }^{7}$ M.Solly Lubis, Filsafat Ilmu dan Penelitian (Bandung: Mandar Maju, 1994), 80.

8Soerjono Soekanto, Pengantar Ilmu Penelitian (Jakarta: UI Pres, 1986), 6; See also Rusli Rusli, "Pendekatan Fenomenologi Dalam Studi Agama Konsep, Kritik Dan Aplikasi," Islamica: Jurnal Studi Keislaman 2, no. 2 (2008): 141-153.

e-ISSN: 2715-4580 p-ISSN: $2715-8268$ 
another, with the aim to explain the observed phenomena. ${ }^{9}$ Because this research is a normative research, the theoretical framework is directed to the theory of legal science.

Justice is an abstract concept. For this reason, it is necessary to formulate a definition that can describe the meaning of justice. There are many definitions of justice. According to Thomas Aquinas, justice can be divided into:

1. General Justice (justitia generalis); namely, justice according to the will of the law, which must be carried out for the public interest.

2. Special justice; namely, justice on the basis of equality or proportionality. ${ }^{10}$ three:

Special justice is divided into

a) Distributive justice (justitia distributive); that is, justice that is proportionally applied in the field of public law in general

b) Commutative justice (justitia cummulativa); that is, justice by equating achievement with counter achievement

c) Vindicative justice (justitia vindicativa); namely, justice in imposing punishment or compensation in criminal acts. A person is considered fair if he is sentenced to corporal punishment or a fine in accordance with the amount of punishment that has been determined for the crime he has committed. ${ }^{11}$

\footnotetext{
9Ibid.

${ }^{10}$ Notohamidjojo, Demi Keadilan dan Kemanusiaan (Jakarta: BPK Gunung Mulia, 1975), 85.

${ }^{11}$ Ibid. 88.
}

According to Yusuf Qardhawi, justice, in Islamic point of view, is giving to all those who are entitled to their rights, either personally or in a congregation, or any value without exceeding or reducing, so as not to reduce their rights and also the rights of others. ${ }^{12}$

The same also applies to the distribution of joint property, each husband and wife have the same rights to joint property in marriage as long as it is not specified in the marriage agreement. In essence, each husband and wife has the same rights in the management of joint assets. In carrying out legal actions on joint assets, the husband or wife must obtain the approval of their spouse. So that in the distribution, each should get the same rights regardless of their respective services.

Through the theory of justice, each litigant who comes to the Religious Courts to resolve conflicts over joint property can obtain justice based on the distribution according to their respective rights. Plaintiffs and defendants or their attorneys, clerks, and panel of judges, must make every effort to resolve the case fairly and fairly without harming either party.

Marriage between a man and a woman will automatically give rise to joint property, which is obtained due to the efforts of a husband or wife or a joint

\footnotetext{
${ }^{12}$ Yusuf Qardhawi, "Keadilan," in Majalah Amanah No. 68 19 December 2005). e-ISSN: 2715-4580 p-ISSN: 2715-8268
} 
effort between husband and wife. ${ }^{13}$ Wealth is also one of the family supports that can bring harmony and happiness. If one family does not suffer from lack, then they can do whatever they want.

In connection with that, there is an assumption in society about the importance of a regulation that regulates joint property in a marriage. Marriage property is a unit of property that is controlled and owned by a family during the marriage. ${ }^{14}$ It implies is that property owned by the husband or wife before marriage, dowry for the wife, as well as inheritance, gifts, and grants belonging to the wife or husband, are not included in joint property. Even in Islam, the property obtained by the wife from the results of her own work does not include joint property, because the property is the property of the wife.

\subsection{Joint Property}

As has been explained, joint property in marriage is property obtained during marriage, and this has been explained in Law no. 1 of 1974 and the Compilation of Islamic Law. In Article 51 of the Human Rights Law, there is also a review of this concept.

a) A wife during the marriage bond has the same rights and responsibilities as her husband for all matters relating to her marital life, relations with her children, and the right to ownership

\footnotetext{
${ }^{13}$ Soermiyati, Hukum Perkawinan Islam dan Undang-undang Perkawinan (Yogyakarta: Liberty, 1999), 8.

${ }^{14}$ Departemen Pendidikan dan Kebudayaan, Kamus Besar Bahasa Indonesia (Jakarta: Balai Putaka, 1988), 327.
}

and management of joint property for household purposes.

b) After the termination of marriage, a woman has the same rights and responsibilities to joint property and taking care of her children, for the best interests of the child.

c) After the termination of marriage, a woman has the same rights as her exhusband on all matters relating to the joint property without reducing the rights of the child, in accordance with the regulation. 15

The assets jointly produced by husband and wife during the marriage period are jointly owned by both. As long as they are still bound in marriage, the property cannot be divided. The assets are equally used by them and divided if they are divorced, either divorced or widowed. 16

\subsection{Prenuptial Property}

Prenuptial Property or "Harta bawaan" is property belonging to each husband and wife obtained before the marriage or as inheritance or gift. As to this type of property, Article 87 paragraph (1) of the Compilation of Islamic Law regulates this kind of asset.

Prenuptial assets are not included in the classification of joint assets. The husband or wife has the right to use their respective assets and can also take legal actions against them. However, inherited property can become joint property if the

${ }^{15}$ Edy Sudibyo, UU No. 39 Tahun 1999 tentang Hak Hasasi Manusia, http://hukum .unsrat.ac.id. (9 June 2019)

${ }^{16}$ Setiawan Budi Utomo, Fiqh Aktual Jawaban Tuntas Masalah Kontemporer (Jakarta: gema insani, 2003), 127.

e-ISSN: $2715-4580$ p-ISSN: 2715-8268 
bride and groom determine this in the marriage agreement they made. Or in other words, the marriage agreement that they agreed on determines the existence of fusion between prenuptial and joint properties. ${ }^{17}$

\subsection{Acquired Assets}

Acquired assets are assets that are only privately owned by each partner (husband and wife) after the marriage bond occurs. These assets may include grants and gifts. This property was not obtained through the joint efforts of both of them during the marriage. The difference is that prenuptial property is obtained before the marriage period, while acquired property is obtained after the marriage period.

As with prenuptial property, this property also becomes the personal property of each partner, both husband and wife, as long as it is not specified otherwise in the marriage agreement. The legal basis is the Compilation, article 87, paragraph (2).

So, the assets obtained during the marriage will be divided if the marriage is broken, either because of death or divorce. The importance of establishing joint property in a marriage is related to control and distribution. The control of joint property occurs if the marriage is still ongoing, while the distribution of joint property is carried out in the case of a breakup of the marriage.

This joint property or gono-gini is regulated in a balanced way, in the sense

17Happy Susanto, Pembagian Harta GonoGini Saat Terjadinya Perceraian (Jakarta: Visi Media, 2008), 15. that the husband or wife controls the property jointly, and each party acts on the property with the approval of the other party. If the marriage breaks up, according to the Compilation of Islamic Law, the property will be divided equally between husband and wife.

\subsection{The Application of Joint Assets in Positive Law}

According to Article 29 of Marriage Law no. 1 of 1974, Chapter V of the Marriage Agreement, it is explained as follows

1) It is said that before or during the marriage takes place, both parties with mutual consent, witnessed by several relatives or other families, may enter into a written agreement ratified by the Marriage Registration Officer, as long as the agreement does not conflict with the law. This also applies to the third parties as long as they are involved.

2) The agreement cannot be ratified if it violates the boundaries of law, religion and morality.

3) The agreement takes effect from the time the marriage takes place, and may not violate the agreement.

4) As long as the marriage lasts, the agreement cannot be changed, unless there is an agreement from both parties to change, and the change does not harm a third party. 18

Meanwhile, in the Civil Code (BW), marriage agreements are generally stipulated in Articles 139-154. In Article 139 it is stated that the prospective

\footnotetext{
18Soemiayati, UU No. 1 Tahun 1974 tentang Perkawinan (Jakarta: 1974), 56.

e-ISSN: 2715-4580 p-ISSN: 2715-8268
} 
husband and wife with a marriage agreement can deviate from the laws and regulations regarding joint property, provided that it does not conflict with good morals or general rules. ${ }^{19}$

If we compare Articles 139-154 of the Civil Code with Article 29 of Marriage Law No. 1 of 1974, there are clearly visible differences. The emphasis of the Civil Code on the unity of assets, while Marriage Law is more open, and it does not only concern material agreements, but also other agreements.

In a marriage ceremony among Muslims, which the author knows, there was an agreement between husband and wife written on stamped paper, and witnessed by the Marriage Registrar and two witnesses, that at the request of the bride, the husband after the marriage would build a good house, and also promised not to marry more than one wife.

If a divorce occurs because the husband remarries another woman, if the house for the wife has not been built by the husband, then the wife has the right to demand that her ex-husband fulfills his promise. However, if the divorce occurs because of the wife's fault, for example, the wife commits adultery, then the wife has no right to sue; instead, she should leave her husband's house. This is a general assumption that basically is influenced by customary and Islamic laws. Maybe for others, the article of the agreement is still valid, and the wife's adultery can be forgiven.

19Subekti, Kitab Undang-Undang Hukum Perdata (Jakarta: Pradnya Paramita 1960), 100.
Commenting on this article, Hazairin stated that the agreement does not include taklik talak in Islamic marriages, which the groom reads in public after the solemnization of a marriage ceremony, is completed, as the it has been determined by the Minister of Religion throughout Indonesia.

Taklik talak that occurs in Indonesia is not bilateral, but unilateral, because it not only binds the one who pronounces it, but also becomes a source of rights for other parties mentioned in the statement. ${ }^{20}$

Taklik talak in short reads, "If I am in a marriage, leave my wife for up to six (6) months, without giving any news, or for up to six months neglecting or ignoring my wife as if she is no longer there, or hurting her, or left scars (body injuries, wounds, bleeding under the skin). Furthermore, for three (3) months of not providing obligatory support to my wife, and my wife was impatient with my treatment, and complained about the matter to the judge (religious court). And the Judge, after examining the situation, confirmed my wife's complaint, and my wife paid the 'iwad money to me through the judge, then one divorce fell from me on my wife, and to the judge I gave full power to use the 'iwad money for the benefit of the poor and orphans." 21

Then, the agreement cannot be ratified, if it violates the boundaries of law, religion and morality. Hazairin

20 Hazairin, Tinjauan Mengenai UU Perkawinan. UU No. 1 Tahun 1974 (Jakarta: Tirta Mas), 28-29.

${ }^{21}$ Ibid. 
pointed out that Article 29 paragraph 2 requires a little comment on religious law and morality. Law without restriction can mean not only statutory law, but also customary law. Religion means not only religious law (if any), but also religious morality. Meanwhile, decency includes not only decency according to religion, but also decency in the sense of social morality, that is generated by the community itself. ${ }^{22}$

In the Civil Code, the rights and obligations of husband and wife are regulated in Chapter V Articles 103-118. The Civil Code begins with the rule that "Husband and wife must be loyal to each other, help each other and help help (Article 103). The binding of husband and wife in marriage means that they are bound in a reciprocal agreement to maintain and educate children (Article 104). The position of the husband is as the Head in the husband-wife union (Article 105). The husband is obliged to accept his wife in his residence (Article 107). Meanwhile, the position of the wife must submit herself to her husband (Article 106)

\section{Methodology}

This study uses qualitative approach $^{23}$ investigating Islamic Law perspectives on joint property sharing. The site of research is the office of Religious Court of Palu, which has

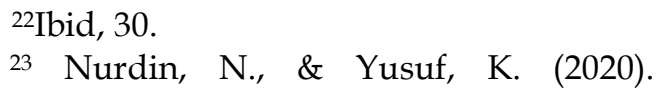

23 Nurdin, N., \& Yusuf, K. (2020). Knowledge management lifecycle in Islamic bank: the case of syariah banks in Indonesia. International Journal of Knowledge Management Studies, 11(1), 59-80. https://doi.org/10.1504/ijkms.2020.105073 authority to examine and decide the cases related to marriage and divorce.

Data were collected through observation, indepth interview with married the religious court staff and judges, and written material24. Data analysis consists of several procedures: reduction and verification techniques with various data sources. ${ }^{25}$ The reduced data is then analyzed reflecting on theoretical concepts used in this study ${ }^{26}$.

\section{Result and Discussion}

\subsection{Method of Joint Property Sharing}

In order to ensure that legal regulations can continue and be accepted by all members of the community, the existing legal regulations must be appropriate and must not conflict with the principles of justice. The distribution of joint assets due to the breakup of marital relations due to divorce in general does not pose much of a problem. This is caused by several things including:

24 Nurdin, Nurdin. (2019). Knowledge Integration Strategy in Islamic Banks. In Almeida Helena \& Sequeira Bernardete (Eds.), The Role of Knowledge Transfer in Open Innovation (pp. 118138). Hershey, PA, USA: IGI Global.

25 Muslih, Imam, Nurdin, Nurdin, \& Marzuki, Marzuki. (2020). Effectiveness of Marriage Services Through Information System Management (SIMKAH) at Palu City Religious Court International Journal of Contemporary Islamic Law And Society, 2(1), 20-35.

26 Iqbal, M., Rusli, R., \& Musyahidah, M. (2019). Management Strategies of Professional Zakat Funds for Mustahiq Family Welfare By Amil Zakat Body International Journal Of Contemporary Islamic Law And Society, 1(1), 39-51.

e-ISSN: $2715-4580$ p-ISSN: 2715-8268 
1. Divorced husband and wife will generally try to choose the path of peace.

2. Proof of joint property can be done by both parties easily.

3. There is no third party who has participated in fighting over the distribution of joint property between husband and divorced wife.

So that the distribution of joint assets can be carried out in accordance with the provisions of Article 97 of the $\mathrm{KHI}$, which states that the distribution is carried out in a balanced way, namely half for the husband and half for the wife. It is different from the distribution of joint property in a state of death, which, in this case, various problems can arise that require special wisdom in solving them.

The division of joint property due to a divorce can be complicated, due to the emergence of a third party as the heirs. ${ }^{27}$ Besides, in general, people feel taboo to immediately divide the joint property between widows or widowers with their children. Delaying the distribution of joint property due to a death divorce will further complicate the distribution of existing joint assets, because evidence of joint property ownership may be lost, transferred or even manipulated by irresponsible parties.

Therefore, the Panel of Judges must be observant in applying the method of dividing joint assets so as to give birth to a sense of justice for everyone who is

${ }^{27}$ Ali Afandi, Hukum Waris Hukum Keluarga Hukum Pembuktian, (4th Edition, Jakarta: PT. Rineka Cipta, 2000). 95. doing litigation. In this case, the judge must be able to read the ultimate goal of law, namely the welfare of mankind. Every decision must also be able to create benefits for all parties. Joint property is a new issue that has no text in the Qur'an. However, the issue of joint property often causes vertical disputes between husband and wife when a divorce occurs.

\subsection{The Analysis of Judge's Decision}

Before making a decision regarding joint property, there must be mediation efforts to make peace between the parties, the plaintiff and the defendant. The mediation stage is important, because if the parties can find a way out of their problems, then the trial process will not proceed to the next stage. ${ }^{28}$

However, in the decision, the author found that mediation was not successful in achieving peace between the two parties. Then, the examination of the case was continued in a trial open to the public by reading out the lawsuit from the Plaintiff, which the content and intent of the Plaintiff are maintained, with such improvements as the identity of the Plaintiff and the Defendant.

Furthermore, the most important stage of analysis is the procedures for the distribution of joint property and the theory of justice.

Does the panel of judges, in the decision on the distribution of joint assets proposed in this case, has a different opinion or their opinion based on the Marriage Law No. 1 of 1974 and the Compilation of Islamic Law? Were all the

\footnotetext{
${ }^{28} \mathrm{Abd}$ Pakih, a judge, "Interview", Religious Court Palu (1 July 2019).

e-ISSN: $2715-4580$ p-ISSN: 2715-8268
} 
plaintiff's claims accepted by the panel of judges by presenting evidence and witnesses? Vice versa, are the arguments of plaintiff fully accepted by the panel of judges by presenting evidence and witnesses?

Legal considerations are something that is very necessary for the panel of judges in deciding cases. In legal considerations, the panel of judges must also be more thorough in examining and adjudicating the case, starting from the evidence to the witnesses.

The law of proof itself is regulated in Article 1865 of the Civil Code, which reads: "Everyone who argues that he has a right, or to confirm his own right or to refute a right of another person, shows something at the case". In the decision Number 685/Pdt.G/2015/PA.Pal, this includes written evidence and witnesses. If they are unable to show evidence, then the arguments contained both as plaintiffs and defendants cannot be considered by the panel of judges.

The legal basis used by the judges in joint property cases refers to Article 35 paragraph (1) of Marriage Law Number 1 of 1974, which stipulates that property acquired during marriage becomes joint property. Then Article 97 of the Compilation of Islamic Law stipulates that divorced widows or widowers are each entitled to one-half of the joint property as long as it is not specified otherwise in the marriage agreement.

In the form of this decision, it can be seen that the panel of judges has tried hard to give a truly fair decision for each party. According to my opinion, in general, the concept of the division of joint property that has been regulated in the Compilation of Islamic Law is the concept of a fair distribution of joint property. That is, the role of a husband who works outside the home to earn money and a wife who works taking care of the household is a balanced role in maintaining the integrity of a household.

So, the assets obtained jointly during the marriage period, whether from the acquisition of husband or wife, are joint assets. Thus, it is only natural that each party gets half of a share, because each party plays the balanced role in the household.

Furthermore, in the examination of joint property disputes, sometimes each party argues that the assets mentioned in the lawsuit or counterclaim are their property, not joint property. In the case above, the author finds that the plaintiff is not cooperative towards the joint property owned during the marriage; the property such as gold appears after the defendant sues again in his compensation.

Furthermore, the defendant in compensation was unable to answer or present the evidence and witnesses to answer the arguments of the plaintiff in compensation. Thus, most of the counterclaim plaintiffs got their rights to a few grams of gold which was decided by the judge.

The panel of judges, based on Article 35 paragraph (1) of Marriage Law Number 1 of 1974 and KHI, may grant a claim for compensation containing the determination of joint assets. According to the author, there is something very important to note, namely the foresight 
and thoroughness of the panel of judges in examining joint property disputes.

Is it true that the assets that have been mentioned in the plaintiff's lawsuit or the compensation suit are the assets obtained by them during the marriage period? If it is proven that they are joint property, the determination of joint property in the judge's decision will be truly fair to each party.

\section{Conclusions}

Based on the results of research at the Palu Religious Court regarding the distribution of joint assets due to divorce at the Palu Religious Court, it can be concluded that the panel of judges in resolving the distribution of assets refers to Article 35 paragraph (1) of Law Number 1 of 1974 and KHI in article 97.

The panel of judges when making a decision conducts in-depth analysis and consideration. This consideration includes all evidence submitted by the plaintiff and defendant in the trial, as well as witness statements. In addition, the panel of judges is able to make decisions according to the procedures. So, automatically, the distribution of joint assets at the Palu religious court has been carried out well.

\section{REFERENCES}

Dapertemen Agama RI, Al-Quran dan Terjemahnya, Bandung: $\quad \mathrm{CV}$ Diponegoro, 2005.

Abdurrahman, Kompilasi Hukum Islam di Indonesia

(Banjarmasin:

Akademika Pressindo, 1992.

Ari, Donal, et. al, Introduction to Research, diterjemahkan oleh Arief Rahman,
Pengantar Penelitian dan Pendidikan, Surabaya: Usaha Nasional, t.th.

Arifin, Imron, Penelitian Kualitatif dalam Ilmu-ilmu Sosial dan Keagamaan, $3^{\text {rd }}$

Edition, Malang: Kalimasada Press, 1996.

Bahry, Zainul, Kamus Umum Khususnya Bidang Hukum dan Politik, Bandung: Angkasa, 1993.

Departeman Pendidikan dan Kebudayaan, Kamus Besar Bahasa Indonesia, Jakarta: Balai Putaka, 1988.

Dapertemen Pendidikan dan Kebudayaan, Kamus Besar Bahasa Indonesia , 299.

Elti, Yunani, "Pembagian Harta Bersama (Gono-Gini) Dalam Praktek di Pengadilan Agama Bandar Lampung" Master Thesis, Program Magister Universitas Ponegoro, Semarang, 2009.

Ezmir, Metodologi Penelitian Kualitatif Analisis Data, 2nd Edition, Jakarta: PT. Raja Grafindo Persada, 2011.

Godal, Thoriq, Analisis Putusan Hakim Mengenai Pembagian Harta Bersama Berdasarkan Besaran Kontribusi Dalam Perkawinan Studi Kasus Pengadilan Agama Kelas 1A Palu Master's Thesis, Pascasarjana, Institut Agama Islam Negeri Palu, 2019.

Harahap, Pembahasan Hukum Perkawinan Nasional Berdasarkan Undangundang Nomor 1 Tahun 1974, Peraturan Pemerintah Nomor 9 Tahun 1974.

Harahap, M. Yahya, Pembahasan Hukum Perkawinan Nasional Berdasarkan Undang-undang Nomor 1 Tahun 1974, Peraturan Pemerintah Nomor 9

e-ISSN: 2715-4580 p-ISSN: 2715-8268 
Tahun 1974, $1^{\text {st }}$ Edition, Medan: Zahir Trading Co, 1975.

Hasballah, Thaib, Hukum Islam di Indonesia, Medan: SPS Ilmu Hukum, 2005.

Ismi Syafriani Nasution, Akibat Hukum Perceraian Terhadap Harta Bersama Berdasarkan Undang-Undang Perkawinan No 1 tahun 1974 dan Kompilasi Hukum Islam Master's Thesis, Pascasarjana Universitas Sumatra Utara, Medan, 2009.

Iqbal, Muhammad, Rusli, Rusli, \& Musyahidah, Musyahidah. (2019). Management Strategies of Professional Zakat Funds for Mustahiq Family Welfare By Amil Zakat Body International Journal of Contemporary Islamic Law And Society, 1(1), 39-51.

Kalo, Syafruddin, Teori dan Penemuan Hukum, Medan: SPS Ilmu Hukum USU, 2004.

Kementerian Pendidikan dan Kebudayaan RI, "Kamus Besar Bahasa Indonesia Daring". Official Website Kamus Besar Bahasa Indonesia Online Kementerian Pendidikan dan Kebudayaan RI. https://kbbi.kemdikbud.go.id/en tri/harta (Accessed: 03 June 2017).

Lubis, M. Solly, Filsafat Ilmu dan Penelitian, Bandung: Bandar Maju, 1994, 80.

Manan, Abdul, Etika Hakim Dalam Penyelenggaraan Peradilan. $1^{\text {st }}$ Edition; Jakarta: Prenada Media Group, 2007.

Margono, S, Metodologi Penelitian Pendidikan, $4^{\text {th }}$ Edition, (Jakarta: Rineka Cipta, 2004
M Fauzan, Abdul Manan, Pokok-pokok Hukum Perdata Wewenang Peradilan Agama, Jakarta: PT Raja Grafindo Persada, 2001.

Moleong, Lexy J, Metodologi Penelitian Kualitatif, Cet. XVII, Bandung: PT. Remaja Rosdakarya, 2002.

Muhammad, Abdul Kadir, Hukum Acara Perdata Indonesia (Bandung: Citra Aditya Bakti, 2000.

Muslih, Imam, Nurdin, Nurdin, \& Marzuki, Marzuki. (2020). Effectiveness of Marriage Services Through Information System Management (SIMKAH) at Palu City Religious Court INTERNATIONAL JOURNAL OF CONTEMPORARY ISLAMIC LAW AND SOCIETY, 2(1), 20-35.

Nagara, Bernadus, Pembagian harta gonogini atau harta bersama Setelah Perceraian,

C: $\mid$ Users $\backslash u \backslash$ Downloads $\backslash 148458$ ID-pembagian-harta-gono-gini-atauharta-ber.pdf, Accessed: 21 April 2019.

Notohamidjojo, Demi Keadilan dan Kemanusiaan, Jakarta: BPK Gunung Mulia, 1975.

Nurdin, Nurdin. (2019). Knowledge Integration Strategy in Islamic Banks. In Almeida Helena \& Sequeira Bernardete (Eds.), The Role of Knowledge Transfer in Open Innovation (pp. 118-138). Hershey, PA, USA: IGI Global.

Nurdin, Nurdin, \& Yusuf, Khaeruddin. (2020). Knowledge management lifecycle in Islamic bank: the case of syariah banks in Indonesia. International Journal of Knowledge 
Management Studies, 11(1), 59-80. doi: $10.1504 / \mathrm{ijkms.2020.105073}$

Qardhawi, Yusuf, "Keadilan" in Majalah Amanah No. 6819 December 2005.

Rato, Dominikus, Hukum Perkawinan dan Waris Adat di Indonesia, Yogyakarta: Laksbang Pressindo, 2015.

Ramulyo, Moh. Idris, Hukum Perkawinan, Hukum kewarisan, Hukum Acara Peradilan Agama dan Zakat menurut Hukum Islam, (Jakarta: Cempaka Putih, 1986).

Rofiq, Ahmad, Hukum Islam di Indonesia (1st Edition; Jakarta: PT Raja Grafindo Persada, 1995), 200.

Ruslan, Rosady, Metode Penelitian Public Relation dan Komunikasi, $4^{\text {th }}$ Edition, Jakarta: PT. Raja Grafindo Persada, 2004.

Rusli, Rusli, "Pendekatan Fenomenologi Dalam Studi Agama Konsep, Kritik dan Aplikasi," Islamica: Jurnal Studi Keislaman 2, no. 2 (2008): 141-153.

Rusli, Rusli, "Hermeneutical Reading of Țalāq," HUNAFA: Jurnal Studia Islamika 12, no. 2 (2016): 209-229.

Samawati Putu, dan Wahyuningsih Ema, Hukum Perkawinan Indonesia, PT. Rambang Palembang, 2006.

S. Margono, Metodologi Penelitian Pendidikan, $4^{\text {th }}$, Jakarta: Rineka Cipta, 2004.

Soermiyati, Hukum Perkawinan Islam dan Undang-undang Perkawinan Yogyakarta: Liberty, 1999.

Soekanto, Soerjono, Pengantar Ilmu Penelitian, Jakarta: UI Pres, 1986.

Subekti, Kitab Undang-Undang Hukum Perdata, Jakarta: Pradnya Paramita 1960.
Sudibyo, Edy, UU No. 39 Tahun 1999 tentang Hak Hasasi Manusia, http:/ / hukum.unsrat.ac.id. June 2019)

Sugiyono, Metode Penelitian Pendidikan Pendekatan Kuantitatif, Kualitatif dan $R D$, 18 th Edition; Bandung: Alfebeta, 2013.

Sukaenah, Sukaenah, Rusli, Rusli, \& B, M. Taufan. (2020). The Effectiveness of Indonesia Supreme Court Regulation Number 1 Year 2016 Concerning Mediation of Marriage Disputes International Journal Of Contemporary Islamic Law And Society, 2(1), 63-80.

Susanto, Dedi, Kupas Tuntas Masalah Harta Gono-Gini, $1^{\text {st }}$ Edition, Yogyakarta: Pustaka Yustisia, 2011, 144.

Suma, Muhammad Amin, Hukum Keluarga Islam di Dunia Islam, $1^{\text {st }}$ Edition, Jakarta: PT Raja Grafindo, 2004.

Surakhmad, Winarno, Dasar dan Teknik Research Pengentar Metodologi Ilmiah Bandung: Torsito, 2000

Susanto, Happy, Pembagian Harta GonoGini Setelah Terjadinya Perceraian n.y.

Syarifuddin, Amir, Hukum perkawinan Islam di Indonesia, 2nd Edition, Jakarta : Prenada Media, 2007.

Thalib, Sayuti, Hukum Kekeluargaan Indonesia, Jakarta: Yayasan Penerbit UI, 1974.

Tihami, M. A. dan Sahrani, Sohari, Fikih Munakahat. $4^{\text {th }}$ Edition, Jakarta: PT Raja Grafindo Persada, 2014. 
Umar, Husein, Metode Penelitian untuk Skripsi dan Tasir Bisnis, $4^{\text {th }}$ Edition, Jakarta: PT. Raja Grafindo, 2010.

Hazairin, Tinjauan Mengenai UU Perkawinan UU No. 1 Tahun 1974, Jakarta: Tirta Mas.

Yunus, Haerunnisa, Rusli, Rusli, \& Abidin, Abidin. (2020). The Concept of A Marriage Agreement in the Compilation of Islamic Law International Journal Of Contemporary Islamic Law And Society, 2 (2), 35-45.

Zainul, Bahry. Kamus Umum Khusus Bidang Hukum dan Politik, Bandung, Angkasa: 1993. 